\title{
Relationship of Soil Properties and Sugarcane Yields to Red Stripe in Louisiana
}

\author{
Richard M. Johnson, Michael P. Grisham, Kathryn Z. Warnke, and Jeri R. Maggio
}

United States Department of Agriculture-Agricultural Research Service, Sugarcane Research Unit, 5883 USDA Rd., Houma, LA 70360. Accepted for publication 10 March 2016.

\begin{abstract}
Johnson, R. M., Grisham, M. P., Warnke, K. Z., and Maggio, J. R. 2016. Relationship of soil properties and sugarcane yields to red stripe in Louisiana. Phytopathology 106:737-744.

Symptoms of red stripe disease caused by Acidovorax avenae subsp. avenae in Louisiana between 1985 and 2010 were limited to the leaf stripe form, which caused no apparent yield loss. During 2010, the more severe top rot form was observed, and a study was initiated to investigate the distribution of red stripe in the field and determine its effects on cane and sugar yields. Soil properties data, red stripe incidence, and sugarcane yields were all highly variable and were not randomly distributed in the field.

Combined harvest data showed a negative correlation between yield components and red stripe incidence, with the strongest relationship between sucrose per metric ton and disease incidence. Red stripe incidence was positively correlated with several soil properties, including phosphorus, potassium, zinc, and calcium. Red stripe incidence also was found to increase with increasing nitrogen rate, with the greatest effects in heavy soils. Results also indicated that using red-stripe-infected cane as a seed source can significantly decrease shoot emergence, stalk population, and subsequent cane and sugar yields. These combined data suggest that red stripe disease can exhibit a highly variable rate of infection in commercial sugarcane fields and may also significantly decrease sugar yields.
\end{abstract}

Red stripe of sugarcane (interspecific hybrids of Saccharum) is caused by Acidovorax avenae subsp. avenae (Manns) Willems et al. The disease may exhibit two forms of symptoms (either separately or together): leaf stripe and top rot (Martin and Wismer 1989; Rott and Davis 2000). In 1927, several new leaf stripe diseases, with symptoms similar to certain tropical bacterial diseases, were reported in Louisiana which, in turn, resulted in one of the first reports of red stripe disease in the state (Christopher and Edgerton 1930). Top rot symptoms observed in 1927 were also noted in another report from Louisiana in 1955 (Edgerton 1955) as a symptom of red stripe; however, symptoms of red stripe observed in the state by the authors between 1985 and 2010 were limited to the leaf stripe form and caused no apparent yield loss. During 2010, the more severe top rot form was observed in several commercial sugarcane fields, primarily in 'HoCP 00-950' sugarcane. Both forms of symptoms were found either separately or together, as reported previously (Martin and Wismer 1961, 1989).

Red stripe has been reported in most sugarcane-producing countries of the world; however, economic loss has been reported only when associated with the top rot form of the disease (Martin and Wismer 1989; Rott and Davis 2000). Bacterial exudates of A. avenae subsp. avenae form on the leaf stripes during warm periods with high rainfall and humidity (Rott and Davis 2000). Transmission of the bacteria is primarily by wind-blown rain from plant to plant (Martin and Wismer 1989; Rott and Davis 2000). Researchers in Queensland, Australia reported that the lower the water-holding capacity of the soil, the higher the incidence of the top rot form of red stripe (Egan and Hughes 1958).

Several researchers have reported that other sugarcane diseases, particularly brown rust, may be influenced by soil properties.

Corresponding author R. M. Johnson;

E-mail address: richard.johnson@ars.usda.gov

http://dx.doi.org/10.1094/PHYTO-09-15-0218-R

This article is in the public domain and not copyrightable. It may be freely reprinted with customary crediting of the source. The American Phytopathological Society, 2016
Research in Florida demonstrated that soil acidity was negatively correlated with rust incidence, whereas high levels of soil phosphorus were positively correlated with rust incidence (Anderson et al. 1990). A similar study in Louisiana confirmed that rust incidence was related to soil properties, with high levels of soil sulfur and phosphorus yielding positive correlations with rust levels (Johnson et al. 2007). In this study, rust incidence and soil properties were spatially correlated in a majority of the cases evaluated, with spatial ranges varying from 20 to $241 \mathrm{~m}$.

This study was undertaken to determine (i) the yield loss potential of red stripe on yield in HoCP 00-950 (Tew et al. 2009), (ii) whether differences in soil properties are associated with the incidence of the top rot symptoms, (iii) whether in-field variation of the disease is spatially correlated and related to the spatial correlation of soil properties, (iv) the influence of nitrogen rate applications on the incidence of red stripe, and (v) the effect of using red-stripe-infected seed cane on subsequent disease incidence and yields.

\section{MATERIALS AND METHODS}

Sampling information and soil classification. Red stripe mapping experiments were conducted in 2010 in production sugarcane fields of HoCP 00-950 (Tew et al. 2009) at two locations: the Magnolia Plantation, Schriever, LA, and the St. Louis Plantation, Plaquemine, LA. The Schriever field was first-ratoon sugarcane and the Plaquemine field was plant-cane (first-year crop) sugarcane. The Schriever research site consisted of 42 rows of cane, $320 \mathrm{~m}$ in length (approximately $2.4 \mathrm{ha}$ ). Interrow spacing was $1.8 \mathrm{~m}$. Six rows (row numbers 4, 9, 16, 23, 30, and 39) were divided into 21 15.2-m plots per row, for a total of 126 plots. The soils at this site were Cancienne silt loam and silty clay loams (fine-silty, mixed, superactive, nonacid, hyperthermic fluvaquentic epiaquepts). The soil type was a silty clay loam at one end of the test, a silt loam toward the middle of the field, and finally a silty clay loam at the other end of the field. The experimental area of the field at Plaquemine included 30 rows, $145 \mathrm{~m}$ long (approximately $0.8 \mathrm{ha}$ ). Interrow spacing was $1.8 \mathrm{~m}$. 
Six rows (rows 7, 14, 15, 16, 17, and 24) were divided into 19 7.6-m plots (one end plot was discarded because of mechanically damaged cane) for a total of 113 plots. The soils at this site included both Commerce silt loam and silty clay loams (fine-silty, mixed, superactive, nonacid, thermic fluvaquentic endoaquepts), with the silt loam soil at one end of the test and the silty clay loam at the other end. At both sites, a handheld computer (Compaq IPAQ; Hewlett Packard, Palo Alto, CA) equipped with a global positioning system (Navman, Raleigh, NC) and mapping software (Site Mate; Farmworks Software, Hamilton, IN) was utilized to determine site boundaries, total plot area, and soil-sampling points.

Soil analysis. Soil samples (0 to $20 \mathrm{~cm}$ ) were collected from each plot at the two locations. Samples were air dried, ground with an electric grinding mill (Straub 4E; QCG Systems, Phoenixville, PA), and shipped for analysis at A\&L Laboratories (Memphis, TN). Soil properties determined included soil organic matter (OM), soil $\mathrm{pH}$, soil buffer $\mathrm{pH}$, exchangeable cations (calcium, magnesium, and potassium), soil cation exchange capacity (CEC), phosphorus, sulfur, sodium, and micronutrients (boron, copper, iron, manganese, and zinc). Phosphorus, major cations, and micronutrients present in soil samples were estimated using the Mehlich 3 extraction procedure and inductively coupled plasma-atomic emission spectrophotometry (EPA Method 200.7). Soil OM was determined by loss on ignition (Nelson and Sommers 1996). Soil $\mathrm{pH}$ was determined in a 1:1 (mass/vol) soil-to-water suspension and soil buffer $\mathrm{pH}$ using the SMP buffer (Thomas 1996). The soil CEC is calculated by summing exchangeable cations. Soil fertility levels were based on A\&L Laboratory recommendations for sugarcane grown in Louisiana.

Red stripe assessment. Disease data were collected on 19 July 2010 (rows 9, 16, 23, and 30) and 3 August 2010 (rows 4 and 39 added) at the Schriever location and on 16 July and 10 August 2010 at the Plaquemine location. Red stripe incidence was determined for each plot based on the percentage of the total number of stalks with visual symptoms (leaf stripe or top rot).

Yield determination. Experimental plots were harvested at the Schriever location on 17 November 2010. At the Plaquemine location, the plant-cane crop was harvested on 6 December 2010. Each experimental plot was harvested with a single-row, chopper harvester (John Deere, Thibodaux, LA) and the total plot weight was determined using a modified single-axle high-dump billet wagon (John Deere) equipped with load sensors mounted on the spindles at the end of the axle and on the wagon's tongue where it connects to the tractor (Johnson and Richard 2005). A billet sampler mounted on the "weigh wagon" was used to capture a random subsample of billets from each plot as they were being transferred from the harvester to the wagon. In 2010, the subsamples of the billeted cane were analyzed by the prebreaker, core press method (Legendre 1992). Extracted juice was analyzed for Brix (percent soluble solids content in cane) and sucrose (percent in cane) and the bagasse was dried to determine fiber (percentage in cane). From the juice analysis results, theoretically recoverable sucrose (TRS) (kilograms per megagram) was calculated. Cane (megagrams per hectare) and sucrose (kilograms per hectare) yields were calculated using plot weights and TRS.

Influence on nitrogen fertilizer on red stripe incidence. An experiment was initiated on 13 May 2010 to determine the influence of supplemental nitrogen $(\mathrm{N})$ fertilizer on cane and sugar yields. Two first-ratoon fields which were planted to HoCP 00-950 received $\mathrm{N}$ at five rates: $0,45,90,134$, and $179 \mathrm{~kg} \mathrm{ha}^{-1}$. One test was on a light (silt loam) soil and the second test on a heavy (clay) soil, with six replications in each test. Plots were three rows wide $(1.8-\mathrm{m}$ interow spacing) by $15.2 \mathrm{~m}$ long and treatments were arranged as a randomized complete block design. During the growing season, symptoms of red stripe were observed in both the light and heavy soil tests. Because the disease incidence appeared to occur at varying levels within the test, it was decided to investigate the potential influence of $\mathrm{N}$ on disease incidence. Red stripe incidence was determined during the growing season, as described above.

Effects of red stripe symptomatic seed cane on subsequent yields. An experiment was planted on 5 August 2010 at the United States Department of Agriculture Sugarcane Research Unit's Ardoyne Research farm in Schriever, LA to determine whether planting seed cane infected with different levels of red stripe would affect cane emergence and subsequent cane and sugar yields. The seed cane was cut from the sugarcane field of HoCP 00-950 in Schriever. Three treatments included (i) seed cane with severe red stripe symptoms, including extensive leaf stripe, top rot, or both symptoms; (ii) seed cane with mild leaf stripe symptoms only; and (iii) seed cane with no red stripe symptoms (control). The seed cane for a fourth treatment was cut to simulate seed cane randomly cut from a field with a high incidence of red stripe, such as would be expected when cutting seed cane with a mechanical harvester. For this treatment, all stalks were cut from a section of row and planted without regard to red stripe symptoms. The experiment was planted in a randomized block design with four replicates. Plots were two rows wide, $1.8 \mathrm{~m}$ between rows, and $7.62 \mathrm{~m}$ in length. To prevent mechanical spread of the pathogen

TABLE 1. Univariate statistics for soil properties from experiments monitoring variability in sugarcane red stripe incidence in two fields Southeast Louisiana during 2010

\begin{tabular}{|c|c|c|c|c|c|c|c|c|c|c|c|c|c|c|}
\hline \multirow[b]{2}{*}{ Statistic ${ }^{z}$} & \multicolumn{14}{|c|}{ Soil properties ${ }^{y}$} \\
\hline & $\mathrm{pH}$ & $\mathrm{P}$ & $\mathrm{K}$ & $\mathrm{Ca}$ & $\mathrm{Mg}$ & $S$ & $\mathrm{~B}$ & $\mathrm{Cu}$ & $\mathrm{Fe}$ & Mn & $\mathrm{Zn}$ & $\mathrm{Na}$ & OM & CEC \\
\hline \multicolumn{15}{|l|}{ St. Louis } \\
\hline Mean & 6.4 & 60 & 242 & 2476 & 469 & 12 & 0.43 & 3.91 & 263 & 91 & 4.1 & 49 & 1.7 & 15.8 \\
\hline Maximum & 7.3 & 133 & 407 & 3570 & 676 & 24 & 1.10 & 5.00 & 333 & 185 & 7.7 & 97 & 2.2 & 19.4 \\
\hline $\mathrm{CV}$ & 5.9 & 36 & 22 & 14 & 18 & 20 & 28.2 & 12.5 & 16.4 & 36 & 31.1 & 24.5 & 11.1 & 14.9 \\
\hline \multicolumn{15}{|l|}{ Magnolia } \\
\hline $\mathrm{CV}$ & 5.5 & 15.6 & 19.1 & 16.4 & 16.5 & 18.2 & 21.5 & 15.8 & 14.5 & 12.5 & 15.1 & 37.5 & 13.5 & 15.1 \\
\hline \multicolumn{15}{|l|}{ Combined } \\
\hline Mean & 6.2 & 36 & 170 & 2003 & 417 & 10 & 0.42 & 3.42 & 324 & 121 & 3.1 & 40 & 1.7 & 13.3 \\
\hline Minimum & 5.3 & 14 & 52 & 470 & 93 & 7 & 0.30 & 1.10 & 115 & 17 & 1.9 & 24 & 1.2 & 3.3 \\
\hline Maximum & 7.3 & 133 & 407 & 3570 & 676 & 24 & 1.10 & 5.00 & 512 & 197 & 7.7 & 156 & 2.3 & 19.4 \\
\hline $\mathrm{CV}$ & 5.9 & 64.1 & 39.6 & 23.8 & 19.8 & 21.4 & 24.2 & 18.2 & 21.0 & 27.8 & 36.6 & 36.3 & 12.7 & 21.1 \\
\hline
\end{tabular}

${ }_{\mathrm{y}}^{\mathrm{y}}$ Univariate statistics for soil pH; Mehlich III extractable phosphorus (P), potassium (K), calcium (Ca), magnesium (Mg), sodium (S), boron (B), copper $(\mathrm{Cu})$, iron $(\mathrm{Fe})$, manganese $(\mathrm{Mn})$, zinc $(\mathrm{Zn})$, and sodium $(\mathrm{Na})\left(\mathrm{mg} \mathrm{kg}^{-1}\right.$ of soil); percent organic matter $(\mathrm{OM})$; and cation exchange capacity $\left(\mathrm{CEC}\right.$, $\left.\mathrm{cmol}(+) \mathrm{kg}^{-1}\right)$.

${ }^{\mathrm{z}}$ Statistics for St. Louis Planting $(n=75$, Area $=0.8$ ha), Magnolia Plantation $(n=126$, Area $=2.4$ ha), and combined $(n=201) ; n=$ total sample number and Area $=$ total grid sampled area $\mathrm{CV}=$ coefficient of variation. 
during the growing season, plots were buffered on each side by a row of red stripe-resistant ' $\mathrm{L}$ 99-233' sugarcane and a $1.5-\mathrm{m}$ of unplanted buffer, followed by $3 \mathrm{~m}$ of L 99-233 sugarcane, and a second $1.5 \mathrm{~m}$ of unplanted buffer separated the plots. Each plot was planted with a total of 10 stalks. The number of shoots per plot and the number of shoots with red stripe symptoms were recorded on 8 October and 9 November 2010. Shoots that emerged in the fall were killed to the ground by winter freezes. Spring shoot counts were made on 18 March 2011. Millable stalk counts, which represent an estimate of the total number of stalks that will be

TABLE 2. Univariate statistics for sugarcane yields and disease levels from experiments monitoring variability in sugarcane red stripe incidence in two fields in Southeast Louisiana during 2010

\begin{tabular}{lccccc}
\hline Statistic $^{\mathrm{z}}$ & Cane & TRS & Sugar & RS1 & RS2 \\
\hline St. Louis & & & & & \\
$\quad$ Mean & 87 & 124 & 10,863 & 6.5 & 24.5 \\
Minimum & 40 & 81 & 3,446 & 0 & 4 \\
Maximum & 137 & 145 & 18,106 & 38.3 & 93.5 \\
CV & 23.1 & 10.1 & 26.0 & 91.9 & 68.4 \\
Magnolia & & & & & \\
Mean & 66.8 & 122 & 8,144 & 9.5 & 11.3 \\
Minimum & 40 & 88 & 4,736 & 2.1 & 2.3 \\
Maximum & 93 & 136 & 12,462 & 44.7 & 37.5 \\
CV & 17.3 & 6.2 & 17.6 & 69.2 & 64.6 \\
Combined & & & & & \\
Mean & 76.6 & 123 & 9,435 & 8.0 & 17.5 \\
Minimum & 40 & 81 & 3,446 & 0 & 2.3 \\
Maximum & 137 & 145 & 18,106 & 44.7 & 93.5 \\
CV & 25.1 & 8.3 & 27.5 & 79.9 & 79.9 \\
\hline
\end{tabular}

y Univariate statistics for cane yield $\left(\mathrm{Mg} \mathrm{ha}^{-1}\right)$, theoretically recoverable sugar (TRS) $\left(\mathrm{kg} \mathrm{Mg}^{-1}\right)$, sugar yield $\left(\mathrm{kg} \mathrm{ha}^{-1}\right)$, and red stripe incidence (\%) at first (RS1) and second (RS2) sampling dates.

z Statistics for total sample number $(n)$, total grid sampled area (Area), and RS assessment dates for St. Louis Planting $(n=113$, Area $=0.8$ ha, RS1 = 16 July and RS210 August 2010), Magnolia Plantation $(n=126$, Area $=2.4$ ha, RS 19 July and RS2 -3 August 2010), and combined $(n=239)$. $\mathrm{CV}=$ coefficient of variation. available for mechanical harvest, were made on 25 August 2011, 2 August 2012, and 20 June 2013. Red rot incidence was also recorded on these dates. The plant-cane and first- and secondratoon crops were harvested on 16 November 2011, 7 November 2012, and 6 November 2013, respectively. Plots were mechanically harvested and subsamples collected as described above. The subsamples were analyzed by the prebreaker, core press method and the results used to calculate cane (megagram per hectare) and sucrose (kilogram per hectare) yields and fiber content.

Statistical analysis. Exploratory and descriptive analyses of red stripe and soil data from both locations were performed by first calculating univariate statistics with SAS PROC UNIVARIATE (SAS Institute, Inc. 2010). Spatial correlations in the red stripe or soil data were summarized using variograms. The variogram measured the average dissimilarity between data points separated by a given distance (Goovaerts 1997). The graphical variogram provides a summary of measured spatial structure of a given property within the experimental location. Prior to variogram analysis, the data were evaluated to determine the existence of linear trends. When an obvious linear trend existed in the variable, spatial data were detrended by fitting a plane surface through each data set (SAS PROC REG), evaluating the surface at each data point, and subtracting the surface from the raw data (Sadler et al. 1998). The variogram was then calculated from the residual values (GS+; Gamma Design Software, Plainwell, MI). In some cases, a decreased search neighborhood was also utilized to construct variograms by limiting the maximum lag distance used in the analysis. The maximum lag distance is the maximum distance between points used in calculation of the variogram. Both of these procedures were used to account for the apparent nonstationarity present in the experimental site. Simple correlation analysis was performed between red stripe, soil, and yield data on each location as well as the combined data set (combined over all locations) with SAS PROC CORR. Correlation results were considered significant if the probability was significant at $(P \leq 0.05)$. Regression analysis was also performed between red stripe data and yield parameters with SAS PROC REG to determine whether yield losses could be

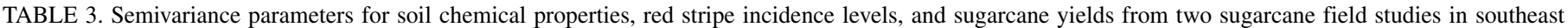
Louisiana during 2010

\begin{tabular}{|c|c|c|c|c|c|c|c|c|}
\hline \multirow[b]{2}{*}{ Date, soil property ${ }^{w}$} & \multicolumn{4}{|c|}{ St. Louis Plantation } & \multicolumn{4}{|c|}{ Magnolia Plantation } \\
\hline & $\operatorname{Ptrt}^{\mathrm{x}}$ & Mlagy & Model $^{\mathrm{z}}$ & Range (m) & Ptrt & Mlag & Model & Range (m) \\
\hline \multicolumn{9}{|l|}{ Rating date } \\
\hline RS1 (16 July 2010) & ND & $\ldots$ & $\mathrm{NC}$ & $\ldots$ & $\ldots$ & $\ldots$ & $\ldots$ & $\ldots$ \\
\hline RS2 (10 August 2010) & $\mathrm{D}$ & 70.4 & $\mathrm{G}$ & 19.4 & $\ldots$ & $\ldots$ & $\ldots$ & $\ldots$ \\
\hline RS1 (19 July 2010) & $\ldots$ & $\ldots$ & $\ldots$ & $\ldots$ & ND & 100 & $\mathrm{E}$ & 70.8 \\
\hline RS2 (3 August 2010) & $\ldots$ & $\ldots$ & $\ldots$ & $\ldots$ & $\mathrm{D}$ & 100 & $\mathrm{~S}$ & 84.2 \\
\hline \multicolumn{9}{|l|}{ Soil property } \\
\hline Soil pH & $\mathrm{D}$ & $\ldots$ & $\mathrm{NC}$ & $\ldots$ & $\mathrm{D}$ & 100 & $\mathrm{~S}$ & 87.1 \\
\hline Phosphorus (mg kg-1) & $\mathrm{D}$ & 70.4 & G & 69.6 & $\mathrm{D}$ & $\ldots$ & $\mathrm{NC}$ & $\ldots$ \\
\hline Potassium $\left(\mathrm{mg} \mathrm{kg}^{-1}\right)$ & ND & 70.4 & $\mathrm{G}$ & 70.7 & $\mathrm{D}$ & 100 & $\mathrm{~S}$ & 94.5 \\
\hline Calcium $\left(\mathrm{mg} \mathrm{kg}^{-1}\right)$ & $\mathrm{D}$ & $\ldots$ & $\mathrm{NC}$ & $\ldots$ & $\mathrm{D}$ & 100 & $\mathrm{~S}$ & 86.3 \\
\hline Magnesium $\left(\mathrm{mg} \mathrm{kg}^{-1}\right)$ & $\mathrm{D}$ & $\ldots$ & $\mathrm{NC}$ & $\ldots$ & $\mathrm{D}$ & 100 & $\mathrm{~S}$ & 86.2 \\
\hline Sulfur $\left(\mathrm{mg} \mathrm{kg}^{-1}\right)$ & ND & $\ldots$ & $\mathrm{NC}$ & $\ldots$ & ND & $\ldots$ & $\mathrm{NC}$ & $\ldots$ \\
\hline Boron $\left(\mathrm{mg} \mathrm{kg}^{-1}\right)$ & ND & $\ldots$ & $\mathrm{NC}$ & $\ldots$ & ND & $\ldots$ & $\mathrm{NC}$ & $\ldots$ \\
\hline Copper $\left(\mathrm{mg} \mathrm{kg}^{-1}\right)$ & $\mathrm{D}$ & $\ldots$ & $\mathrm{NC}$ & $\ldots$ & $\mathrm{D}$ & 100 & $\mathrm{~S}$ & 91.4 \\
\hline Iron $\left(\mathrm{mg} \mathrm{kg}^{-1}\right)$ & $\mathrm{D}$ & $\ldots$ & $\mathrm{NC}$ & $\ldots$ & $\mathrm{D}$ & 100 & $\mathrm{~S}$ & 42.8 \\
\hline Manganese $\left(\mathrm{mg} \mathrm{kg}^{-1}\right)$ & $\mathrm{D}$ & 70.4 & $\mathrm{G}$ & 69.8 & $\mathrm{D}$ & $\ldots$ & $\mathrm{NC}$ & $\ldots$ \\
\hline $\operatorname{Zinc}\left(\mathrm{mg} \mathrm{kg}^{-1}\right)$ & ND & 70.4 & G & 73.3 & ND & 100 & $\mathrm{~S}$ & 55 \\
\hline Sodium $\left(\mathrm{mg} \mathrm{kg}^{-1}\right)$ & ND & $\ldots$ & $\mathrm{NC}$ & $\ldots$ & ND & $\ldots$ & $\mathrm{NC}$ & $\ldots$ \\
\hline Organic matter $(\%)$ & $\mathrm{D}$ & $\ldots$ & $\mathrm{NC}$ & $\ldots$ & $\mathrm{D}$ & $\ldots$ & $\mathrm{NC}$ & $\ldots$ \\
\hline CEC (mEquation $100 \mathrm{~g}^{-1}$ ) & $\mathrm{D}$ & $\ldots$ & $\mathrm{NC}$ & $\ldots$ & $\mathrm{D}$ & 100 & $\mathrm{G}$ & 76.2 \\
\hline Cane yield $\left(\mathrm{Mg} \mathrm{ha}^{-1}\right)$ & $\mathrm{D}$ & 70.4 & $\mathrm{~S}$ & 34.7 & $\mathrm{D}$ & 100 & $\mathrm{E}$ & 48.9 \\
\hline TRS $\left(\mathrm{kg} \mathrm{Mg}^{-1}\right)$ & ND & 70.4 & $\mathrm{E}$ & 28.5 & $\mathrm{D}$ & $\ldots$ & $\mathrm{NC}$ & $\ldots$ \\
\hline Sugar yield $\left(\mathrm{kg} \mathrm{ha}^{-1}\right)$ & ND & 70.4 & $\mathrm{E}$ & 6.0 & $\mathrm{D}$ & $\ldots$ & $\mathrm{NC}$ & $\ldots$ \\
\hline
\end{tabular}

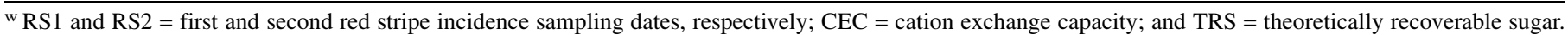

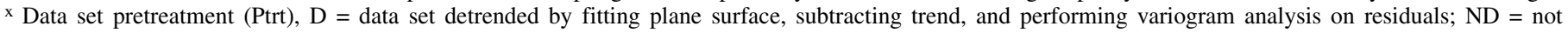
detrended.

y Maximum lag distance (meters) used in variogram fitting.

z Proposed variogram model: $\mathrm{E}=$ exponential, $\mathrm{S}=$ spherical, $\mathrm{G}=$ Gaussian, $\mathrm{L}=$ linear, and NC = not spatially correlated. 
more clearly quantified. This analysis was performed on data from each location as well as the combined data set with a significance level of $P \leq 0.05$. Finally, maps were constructed by block kriging (Surfer; Golden Software, Golden CO) utilizing the previously determined variograms to determine whether spatial patterns existed within each field. Data from $\mathrm{N}$ and seed cane experiments were analyzed using SAS with PROC MIXED (SAS Institute, Inc. 2010), with differences between treatment least square means compared using the PDIFF option (Saxton 1998) at the 0.05 probability level.
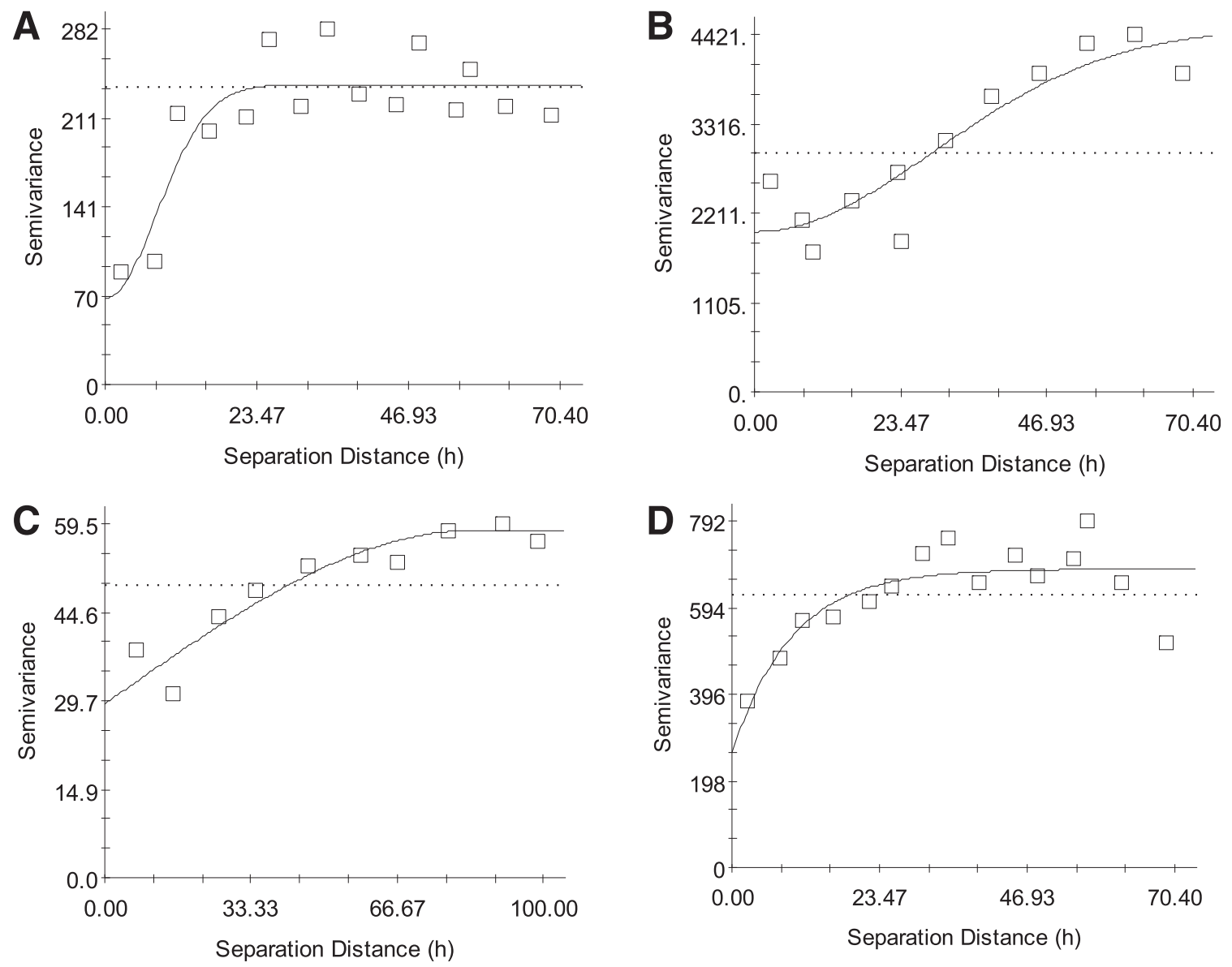

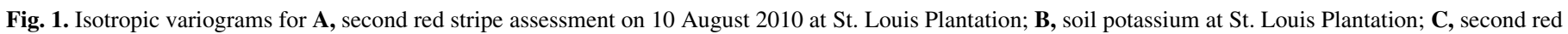
stripe assessment on 3 August 2010 at Magnolia Plantation; and D, theoretically recoverable sucrose levels St. Louis Plantation.
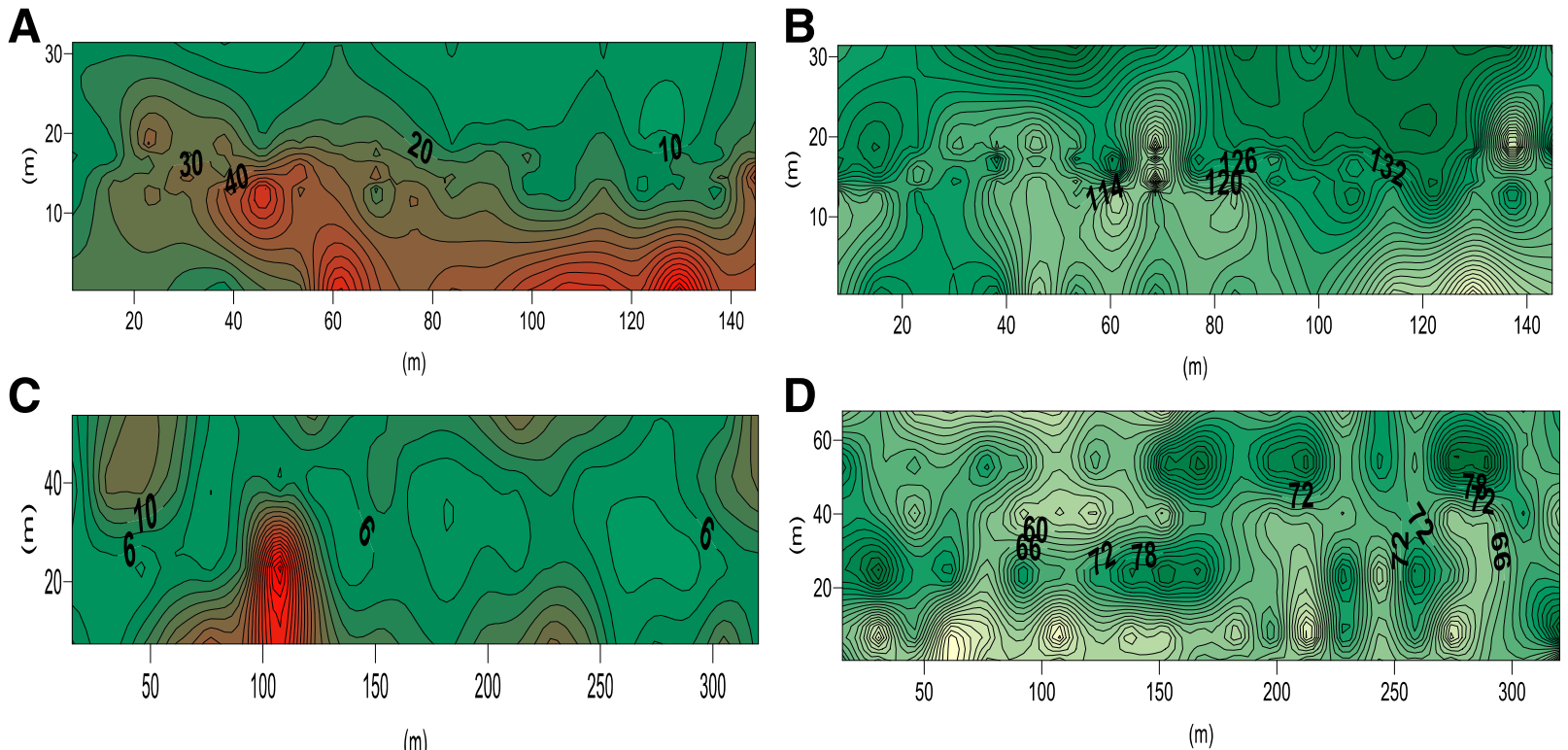

(m)

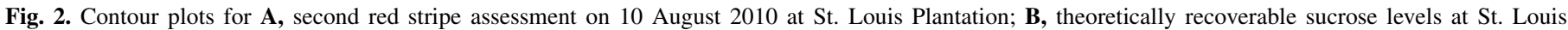
Plantation; C, first red stripe assessment on 19 July 2010 at Magnolia Plantation; and D, cane yield (tons) at Magnolia Plantation. 


\section{RESULTS}

Soil properties. The soil property data displayed significant variability at all locations; however, the most variable properties at each location were different (Table 1). In addition, the overall fertility level at each site was also different. At the first site on St. Louis Plantation, the most variable properties were soil phosphorus, manganese, zinc, boron, sodium, and potassium, with coefficients of variation $(\mathrm{CV})$ of $36,36,31,28,25$, and $22 \%$, respectively. The fertility level at this site was optimum to very high for phosphorus and potassium, low to medium for sulfur and boron, medium for calcium and manganese, very high for magnesium, and optimum to very high for copper, iron, and zinc. In contrast, at Magnolia Plantation, soil sodium was the most variable property, with a $\mathrm{CV}$ of $38 \%$, followed by soil boron, potassium, sulfur, magnesium, and calcium, with CV of $22,19,18,17$, and $16 \%$, respectively. The fertility levels of this location were medium to very high for magnesium and iron, low for sulfur and sodium, low to medium for boron and calcium, and medium to optimum for copper. Soil phosphorus, potassium, calcium, manganese, and zinc tested medium.

Red stripe incidence. The levels of red stripe incidence varied markedly between both locations and also between sampling times (Table 2). At the first sampling time, disease levels were slightly higher at Magnolia Plantation, with an observed range varying from 2.1 to $44.7 \%$ infected stalks and a CV of $69 \%$. At St. Louis Plantation, the levels ranged from 0 to $38.0 \%$, with a CV of $92 \%$ at the first sampling. At the second sampling time, disease levels remained relatively constant at Magnolia Plantation, with disease levels ranging from 2.3 to $37.5 \%$ and a $\mathrm{CV}$ of $65 \%$. In contrast, at St. Louis Plantation, disease levels increased significantly, with disease levels ranging from 4 to $94 \%$ with a CV of $68 \%$.

Sugarcane yields. Sugarcane yields exhibited considerable variability at both locations, with the site at St. Louis Plantation showing greater variability than the site at Magnolia Plantation (Table 2). At St. Louis Plantation, the greatest variability was observed in sugar yields, followed by cane yields and TRS, with CV of 26, 23, and 10\%, respectively. Cane yields at St. Louis Plantation ranged from 40 to $137 \mathrm{Mg} \mathrm{ha}^{-1}$, TRS from 81 to $145 \mathrm{~kg} \mathrm{Mg}^{-1}$, and sugar yield from 3,446 to $18,106 \mathrm{~kg} \mathrm{ha}^{-1}$. At Magnolia Plantation, the greatest variability was also observed with sugar yields, followed by cane yield and TRS, with CV of 18,17 , and $6 \%$, respectively (Table 2). Cane yields at magnolia Plantation ranged from 40 to 93 $\mathrm{Mg} \mathrm{ha}^{-1}$, TRS from 88 to $136 \mathrm{~kg} \mathrm{Mg}^{-1}$, and sugar yields from 4,730 to $12,462 \mathrm{~kg} \mathrm{ha}^{-1}$.

Spatial variability. The data from soil, red stripe, and sugarcane yield variogram analysis are summarized in Table 3. At St. Louis Plantation, the majority of soil properties were not spatially correlated; however, soil phosphorus, potassium, manganese, and boron were found to be correlated (Table 3). In contrast, at Magnolia
Plantation, the majority of soil properties were spatially correlated, which would indicate that the distribution of these properties was spatially dependent (nonrandom), with soil phosphorus, sulfur, boron, manganese, sodium, and OM not correlated. At both locations, the spatial dependence was satisfactorily described with isotropic variograms, although a small degree of anisotropy was suggested. Isotropic (omnidirectional) variograms describe the spatial structure in any direction. Anisotropic (directional) variograms describe the structure in one direction (Isaaks and Srivastava 1989). If significant anisotropy exists in the data, then a series of directional variograms would be necessary. Red stripe levels were found to be spatially correlated at the second sampling period at St. Louis Plantation and at both sampling periods at Magnolia Plantation (Table 3). Cane and sugar yields and TRS were all spatially correlated at St. Louis Plantation but only cane yield was spatially correlated at Magnolia Plantation (Table 3). The variogram models that described the individual soil properties, red stripe levels, and sugarcane yields varied between locations and between the individual properties investigated, with properties described by exponential, spherical, and Gaussian variograms. For example, the soil properties and red stripe ratings measured at the St. Louis Plantation were all described by Gaussian variograms, with ranges varying from 19 to $73 \mathrm{~m}$ (Table 3), while sugarcane yields required both spherical and exponential variograms, with ranges varying from 6 to $34 \mathrm{~m}$ (Table 3). At distances greater than the range, samples are no longer spatially dependent and are considered to be randomly distributed. Gaussian variograms used to describe the second red stripe rating and soil potassium for St. Louis Plantation are shown in Figure 1A and B. The close agreement in variogram structure between these two parameters would suggest that soil potassium could serve as a spatial predictor for red stripe infection level, although the spatial range for potassium is greater than that for red stripe, indicating that the additional properties may be required to adequately describe that spatial structure.

At Magnolia Plantation, it was necessary to include spherical and exponential variograms to adequately describe some of the soil properties, red stripe levels, and sugarcane yields, and the ranges varied from 43 to $95 \mathrm{~m}$ (Table 3). The spherical variogram used to describe the second red stripe infection level at Magnolia Plantation is shown in Figure 1C. Several other soil properties from Magnolia Plantation possessed similar variogram structures and ranges, including soil $\mathrm{pH}$, potassium, calcium, magnesium, and CEC. This suggests that it may be possible to model the spatial variability in red stripe by using soil properties. Finally, the exponential variogram describing TRS levels at St. Louis Plantation is shown in Figure 1D. Again, the similarity in spatial ranges between the variogram describing red stripe levels at St. Louis Plantation (Fig. 1A) and the TRS levels at harvest suggests that a relationship exists between these two factors. The possible use of cokriging to predict

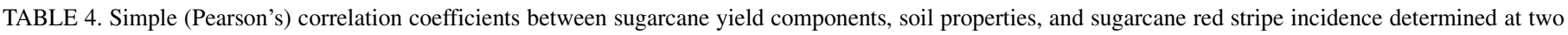
dates in two fields in South Louisiana during 2010y

\begin{tabular}{|c|c|c|c|c|c|c|c|c|c|c|c|c|c|c|c|c|c|}
\hline Rating $^{\mathrm{z}}$ & Tons & TRS & Sugar & $\mathrm{pH}$ & $\mathrm{P}$ & $\mathrm{K}$ & $\mathrm{Ca}$ & $\mathrm{Mg}$ & $\mathrm{S}$ & B & $\mathrm{Cu}$ & $\mathrm{Fe}$ & $\mathrm{Mn}$ & $\mathrm{Zn}$ & $\mathrm{Na}$ & OM & CEC \\
\hline \multicolumn{18}{|l|}{ St. Louis } \\
\hline RS1 & $\mathrm{ns}$ & $-0.35 * * *$ & ns & ns & ns & $\mathrm{ns}$ & $\mathrm{ns}$ & ns & $\mathrm{ns}$ & $\mathrm{ns}$ & ns & $-0.24 *$ & ns & $\mathrm{ns}$ & ns & $\mathrm{ns}$ & $-0.24 *$ \\
\hline RS2 & $\mathrm{ns}$ & $-0.61 * * *$ & $-0.32 * * *$ & $0.24 *$ & $\mathrm{~ns}$ & $\mathrm{~ns}$ & $\mathrm{~ns}$ & $\mathrm{~ns}$ & $\mathrm{~ns}$ & $\mathrm{~ns}$ & ns & $\mathrm{ns}$ & ns & $\mathrm{ns}$ & $\mathrm{ns}$ & $\mathrm{ns}$ & $\mathrm{ns}$ \\
\hline \multicolumn{18}{|l|}{ Magnolia } \\
\hline RS1 & $\mathrm{ns}$ & $-0.38 * * *$ & $-0.26^{*}$ & ns & ns & ns & ns & ns & ns & ns & ns & ns & ns & $-0.24 *$ & ns & ns & ns \\
\hline RS2 & $-0.24 * *$ & $-0.36^{* * * *}$ & $-0.36^{* * * *}$ & ns & $\mathrm{ns}$ & ns & ns & ns & $0.26 * *$ & ns & ns & ns & ns & $-0.24 * *$ & ns & $\mathrm{ns}$ & Ns \\
\hline \multicolumn{18}{|l|}{ Combined } \\
\hline RS1 & ns & $-0.34 * * *$ & $-0.21 * *$ & ns & $\mathrm{ns}$ & $-0.19^{*}$ & $-0.24 *$ & $-0.21 * *$ & $-0.17 *$ & ns & $-0.17^{*}$ & ns & ns & $\mathrm{ns}$ & ns & $\mathrm{ns}$ & $-0.24 * *$ \\
\hline RS2 & $-0.14^{*}$ & $-0.44 * * *$ & ns & $0.20 * *$ & $0.47 * * *$ & $0.47 * * *$ & $0.37 * * *$ & $0.26 * * *$ & $0.23 * * *$ & ns & $0.31 * * *$ & $-0.44 * * *$ & $-0.30 * * *$ & $0.42 * * *$ & $0.25^{* * *}$ & ns & $0.33 * * *$ \\
\hline
\end{tabular}

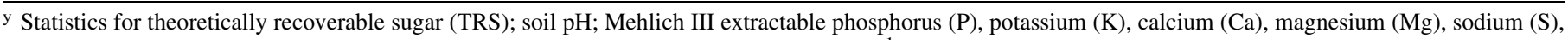
boron $(\mathrm{B})$, copper $(\mathrm{Cu})$, iron $(\mathrm{Fe})$, manganese $(\mathrm{Mn})$, zinc $(\mathrm{Zn})$, and sodium $(\mathrm{Na})\left(\mathrm{mg} \mathrm{kg}^{-1}\right.$ of soil); percent organic matter $(\mathrm{OM})$; and cation exchange capacity $\left(\mathrm{CEC}, \mathrm{cmol}(+) \mathrm{kg}^{-1}\right) ; * * *$, and $* * *$ indicate significant at the $0.05,0.01$, and 0.001 probability levels, respectively; ns $=$ not significant. Statistics are for St. Louis Planting $(n=75$, Area $=0.8$ ha), Magnolia Plantation $(n=126$, Area $=2.4$ ha $)$, and combined $(n=239)$; $n=$ total sample number and Area $=$ total grid sampled area.

z RS1 = first red stripe assessment, 16 or 19 July 2010, and RS2 = second assessment, 10 or 3 August 2010, for St. Louis and Magnolia, respectively. 
red stripe levels from soil properties will be investigated in future research.

Relationships between soil properties, sugarcane yields, and red stripe incidence. Soil samples were taken at the same time that initial red stripe ratings were made. At the first St. Louis Plantation sampling time, only soil iron and the CEC exhibited significant correlations (albeit weak) between red stripe rating and soil parameters $(r=-0.24$ and $-0.24, P \leq 0.05)$ (Table 4$)$. At the second sampling time, only soil $\mathrm{pH}(0.24, P \leq 0.05)$ was found to be significantly correlated with red stripe ratings. Similar results were observed at Magnolia Plantation, with only soil zinc significantly correlated with red stripe ratings at the first sampling $(r=-0.24$, $P \leq 0.05)$ and soil sulfur at the second sampling $(r=0.26, P \leq 0.05)$ (Table 4). The data from both locations were combined to further explore the relations between soil properties and red stripe levels. It was postulated that, by increasing the sample number and range in soil properties, it may be possible to more clearly discern this relationship. When the data were combined by location, several soil properties were found to be significantly correlated with red stripe levels, including soil potassium, calcium, sulfur, and copper $(r=-0.19,-0.24,-0.17$, and -0.17 , respectively, $P \leq 0.05$ ) (Table 4). At the second sampling date, an even greater number of soil properties exhibited a relationship with red stripe levels. Soil $\mathrm{pH}(r=0.20, P \leq 0.05)$, and soil phosphorus, potassium, calcium, magnesium, sulfur, copper, zinc, sodium, and CEC ( $r=0.47,0.47$, $0.37,0.26,0.23,0.31,0.42,0.25$, and 0.33 , respectively, $P \leq 0.001$ ) yielded significant correlations (Table 4 ).

Sugarcane yields were also significantly correlated with red stripe levels in a majority of cases. At St. Louis Plantation, only TRS was correlated with red stripe levels at the first rating period ( $r=-0.35, P \leq 0.001)$ but, at the second rating period, both TRS and sugar yield exhibited a relationship with red stripe $(r=-0.61$ and $r=-0.32, P \leq 0.001)$ (Table 4). At Magnolia Plantation, TRS and sugar were correlated with red stripe levels at the first rating period $(r=-0.38, P \leq 0.001$ and $r=-0.26, P \leq 0.05$ ) and tons, TRS, and sugar were correlated at the second rating period $(r=-0.24, P \leq 0.01 ; r=-0.36, P \leq 0.001 ;$ and $r=-0.36, P \leq$ 0.001 , respectively) (Table 4$)$. Finally, in the combined data set, TRS and sugar were correlated with red stripe levels at the first data set $(r=-0.34, P \leq 0.001$ and $r=-0.21, P \leq 0.01)$ and tons and TRS were correlated at the second rating period $(r=-0.14, P \leq$ 0.05 and $r=-0.44, P \leq 0.001$ ) (Table 4).

Regression analysis was performed between red stripe levels and yield parameters at both sampling times using the data from each location and the combined data sets (data not shown). The strongest correlations were observed between TRS and red stripe levels, with coefficients of multiple correlation of $0.21,0.19$, and 0.17 ( $P \leq$ 0.001) for the St. Louis Plantation, Magnolia Plantation, and the combined data set, respectively. If the incidence level was assumed to be $25 \%$ at both sampling times, the predicted decrease in TRS was 12 , 9, and $11 \%$ for St. Louis Plantation, Magnolia Plantation, and the combined data set, respectively. If an incidence level of $50 \%$ was assumed for both sampling periods, the losses in TRS were 23, 17 , and $22 \%$ for St. Louis Plantation, Magnolia Plantation, and the combined data set, respectively.

Sugarcane yields and red stripe contour maps. Selected soil and red stripe severity maps are presented in Figure 2A to D. An examination of Figure $2 \mathrm{~A}$ and $\mathrm{B}$ suggests that a strong relation exists between red stripe incidence and sugarcane TRS levels at St. Louis Plantation. The red stripe levels are clearly higher on the lower central and right boundaries of Figure 2A (red areas) and correspond directly with lower TRS levels in the same area of Figure 2B (yellow areas). In a similar fashion, the relationship between red stripe levels and cane yields is demonstrated in Figure 2C and D. Higher red stripe levels (red) are seen in several areas in Figure $2 \mathrm{C}$ and many of these correspond with lower cane yields (yellow) in the same area, albeit not as strongly as in Figure 2A and $\mathrm{B}$.
Influence of $\mathbf{N}$ fertilizer on red stripe incidence. The incidence levels of red stripe observed in two $\mathrm{N}$ fertility trials were related to applied $\mathrm{N}$ rate with correlation coefficients of $r=0.68$ $(P=0.0001)$ and $0.79(P=0.0001)$ for light and heavy soils, respectively (data not shown). In both the light soil (silt loam) $\mathrm{N}$ trial and the heavy soil (clay) $\mathrm{N}$ trial, significant differences in stalk numbers with red stripe symptoms were observed (Table 5). However, these differences were greater in the heavy soil test. In the light soil test, there were a significantly higher number of symptomatic stalks when $\mathrm{N}$ was applied compared with the zero $\mathrm{N}$ control. There was no difference among the $\mathrm{N}$ rate treatments. In the heavy soil test, there was a significant difference between plots of the two lowest rates and the two higher rates. The plots with the highest rate of $\mathrm{N}$ had more symptomatic stalks than the lower three rates.

Effects of red stripe symptomatic seed cane on subsequent yields. Red stripe symptoms (leaf stripe form only) were observed among sugarcane shoots that emerged in fall 2010, following planting. The percentages of shoots with symptoms were $0,0,9$, and $0 \%$ on 9 September; $0,10,12.5$, and $3 \%$ on 8 October; and $0,0,5$, and $1 \%$ on 9 November 2010 in the control, mild, severe, and harvest-simulated treatment plots, respectively. Counts of shoot emergence 35, 64, and 125 days after planting were significantly correlated with the seed source utilized (Table 6). When stalks exhibiting severe symptoms of red stripe were utilized as seed, shoot counts were significantly lower than the asymptomatic control at all times. The harvester simulated treatment was significantly lower than the control at the first sampling time but was equivalent at all other times (Table 6). Finally, when stalks that only exhibited the milder red stripe symptoms were used as seed, shoot counts were statistically equivalent to the control. Red stripe symptoms were not observed while making shoot and stalk counts in the plant-cane. In total, 15 stalks were observed with leaf stripe symptoms in the first-ratoon crops and 4 among the mild, 8 among the severe, and 3 among the harvest-simulated treatment plots. Only three stalks across all treatments were observed with leaf stripe symptoms in the second-ratoon crop and one in the mild and two in the harvestsimulated plots. Millable stalk counts, which represent an estimate of the number of stalks expected at harvest, did not show an effect due to seed source in the plant-cane crop (Table 6). In the firstratoon crop, the control exhibited a significantly higher number of stalks than the mildly affected seed source which, in turn, had a significantly greater number of stalks than the severely affected seed source. In the second-ratoon crop, the severely affected seed source had significantly fewer stalks than the other treatments.

In the plant-cane crop, there was not a difference in cane or sugar yields due to the seed source used at planting; however, a trend was present that suggested lower cane and sugar yields when mild or severely infected stalks were used as a seed source (Table 7). There were also no effects of seed source on TRS or fiber content. In the first-ratoon crop, significant differences were observed in both cane and sugar yields due to seed source, with the severely infected seed source showing lower cane and sugar yields (Table 7). No differences were observed in TRS or fiber content. Finally, in the second-ratoon crop, there were no differences in cane or sugar yields or fiber content due to seed source used at planting. A significant difference was observed in TRS, with the severely infected seed source treatment yielding a higher TRS than the control or mildly infected seed source (Table 7).

\section{DISCUSSION}

Significant variability was observed in soil properties from the two locations, with the coefficients of variation ranging from 6 to $64 \%$. Soil phosphorus exhibited the greatest degree of variability and soil $\mathrm{pH}$ the least. The overall fertility levels of each location were also quite variable. The site at St. Louis Plantation had the highest fertility levels, with 6 of 11 fertility components reaching 
optimum or very high levels at sampling points, 4 components having medium levels, and 1 component exhibiting a low level. In contrast, the site at Magnolia Plantation had only 3 components in the optimum or very high levels, with a majority of components ( 6 of 11) in the medium range and 2 in the low level. In general, it was noted that the levels of red stripe infection were found to be higher at St. Louis Plantation, which had a higher number of fertility components in the optimum or very high levels.

In addition to the observed variability, soil properties, red stripe incidence, and sugarcane yields were found to be spatially correlated in 21 of 42 site-location date combinations. Red stripe incidence was found to be spatially correlated in $75 \%$ of the cases, sugarcane yields in $100 \%$ of the cases, and soil properties in $46 \%$ of the cases. The spatial dependence of the measured soil properties has been described in other Louisiana sugarcane fields (Johnson and Richard 2005) and, in a related study, brown rust levels were also found to be spatially correlated and related to variations in soil properties (Johnson et al. 2007). This spatial dependence would indicate that the distribution of red stripe, sugarcane yields, and soil properties within the study sites was not random, as is typically assumed in agricultural trials. It is also important to note that the range of spatial correlation is similar for the some of the measured

TABLE 5. Influence of nitrogen fertility rate on the incidence of red stripe in sugarcane HoCP 00-950 in two fields in South Louisiana in 2010

\begin{tabular}{lcc}
\hline & \multicolumn{2}{c}{ Stalks with red stripe symptoms ${ }^{\mathrm{z}}$} \\
\cline { 2 - 3 } Treatments $\left(\mathrm{N}\right.$ in $\left.\mathrm{kg} / \mathrm{ha}^{2}\right)$ & Heavy soil & Light soil \\
\hline 179.2 & $142 \mathrm{a}$ & $97 \mathrm{a}$ \\
134.4 & $128 \mathrm{ab}$ & $94 \mathrm{a}$ \\
89.6 & $106 \mathrm{bc}$ & $92 \mathrm{a}$ \\
44.8 & $91 \mathrm{c}$ & $83 \mathrm{a}$ \\
0 (control) & $34 \mathrm{~d}$ & $28 \mathrm{~b}$ \\
\hline
\end{tabular}

${ }^{\mathrm{z}}$ Means followed by the same lowercase letter are not statistically different using the $F$ probability values and the PROC MIXED macro as described by Saxton (1998) at $\alpha=0.05$. soil properties and red stripe, suggesting a possible link between the two parameters. There was also a relation between the spatial structure and range of sugarcane yields and red stripe ratings, suggesting that the variation in red stripe infection may be associated with variation in sugarcane yields.

Several interesting trends become apparent when the correlation data are examined. There were few correlations noted between soil properties and red stripe incidence when individual sites were evaluated. This changed significantly when the sites were combined to increase the range in soil properties and red stripe ratings. In this combined data set, positive correlations were observed between red stripe ratings and a number of soil properties at the second rating period, including soil phosphorus, potassium, zinc, and calcium. These results are similar to a study that related variation in soil properties to severity of brown rust in Louisiana (Johnson et al. 2007). A similar relation between brown rust incidence and soil properties was reported in Florida (Anderson et al. 1990). In the present study, the positive relationship between red stripe and soil properties was only observed in the last assessment period with higher disease incidence. At the first assessment, the correlations were negative and of a lower significance level, indicating a more tenuous relationship. In contrast, the relationship between sugarcane yield components and red stripe incidence appeared to be stronger, with significant correlations observed in over $70 \%$ of the cases. The most consistent relationship appeared to be with TRS, in which significant negative correlations were observed in all cases $(r=-0.34$ to $-0.61, P \leq 0.001)$. The second most consistent relationship was with sugar per hectare, which is logical due to the fact that sugar per hectare is derived from cane yield and TRS. Cane yield was the yield component that possessed the weakest association with red stripe disease. Regression data demonstrated that red stripe can significantly decrease TRS when incidence levels increased above $25 \%$ (which occurred at both locations at some sampling locations). These data predicted the highest losses at St. Louis Plantation, where the red stripe incidence levels were the greatest. From these data, it is apparent that red stripe may have a negative effect on sugar yields per hectare, primarily due to the

TABLE 6. Effect of planting seed cane of sugarcane HoCP 00-950 with variable red stripe incidence levels on shoot and stalk counts during three growing seasons $(2010 \text { to } 2013)^{\mathrm{y}}$

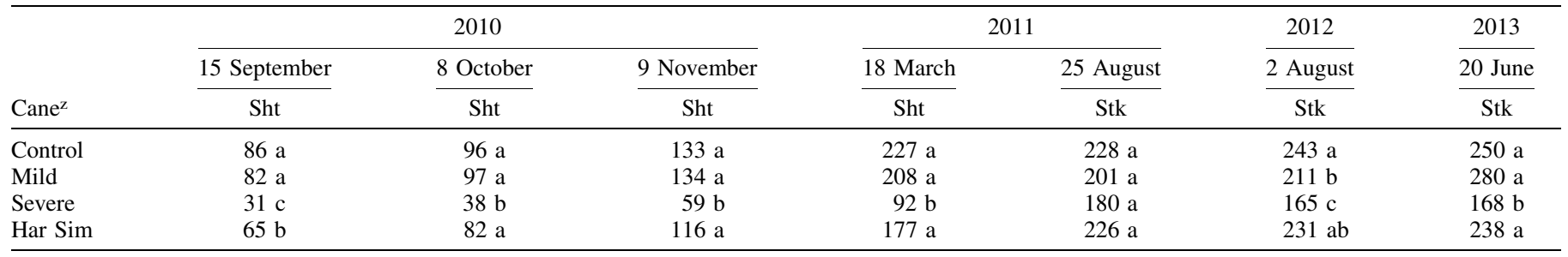

${ }^{\text {y }}$ Sht $=$ average number of emerged shoots and Stk = average number of millable stalks per plot. Means followed by the same lowercase letter are not statistically different using the $F$ probability values and the PROC MIXED macro as described by Saxton (1998) at $\alpha=0.05$.

z Description of seed cane: Control = no red stripe symptoms evident in seed cane; Mild = mild leaf stripe symptoms only; Severe = extensive leaf stripe, top rot, or both symptoms severe symptoms; and Har Sim = simulated harvester cut seed cane with random red stripe incidence.

TABLE 7. Effect of planting seed cane of sugarcane HoCP 00-950 with variable incidence of red stripe on yield and juice quality during three growing seasons $(2010 \text { to } 2013)^{\mathrm{y}}$

\begin{tabular}{|c|c|c|c|c|c|c|c|c|c|c|c|c|}
\hline \multirow[b]{2}{*}{ Cane $^{\mathrm{z}}$} & \multicolumn{4}{|c|}{2011} & \multicolumn{4}{|c|}{2012} & \multicolumn{4}{|c|}{2013} \\
\hline & $\begin{array}{c}\text { Cane } \\
\left(\mathrm{Mg} \mathrm{ha}^{2}\right)\end{array}$ & $\begin{array}{l}\text { Sucrose } \\
\left(\mathrm{kg} \mathrm{ha}^{2}\right)\end{array}$ & $\begin{array}{c}\text { TRS } \\
\left(\mathrm{kg} \mathrm{Mg}^{2}\right)\end{array}$ & Fiber (\%) & $\begin{array}{c}\text { Cane } \\
\left(\mathrm{Mg} \mathrm{ha}^{2}\right)\end{array}$ & $\begin{array}{l}\text { Sucrose } \\
\left(\mathrm{kg} \mathrm{ha}^{2}\right)\end{array}$ & $\begin{array}{c}\text { TRS } \\
\left(\mathrm{kg} \mathrm{Mg}^{2}\right)\end{array}$ & Fiber $(\%)$ & $\begin{array}{c}\text { Cane } \\
\left(\mathrm{Mg} \mathrm{ha}^{2}\right)\end{array}$ & $\begin{array}{c}\text { Sucrose } \\
\left(\mathrm{kg} \mathrm{ha}^{2}\right)\end{array}$ & $\begin{array}{c}\text { TRS } \\
\left(\mathrm{kg} \mathrm{Mg}^{2}\right)\end{array}$ & Fiber $(\%)$ \\
\hline Control & $97 \mathrm{a}$ & $12269 \mathrm{a}$ & $128 \mathrm{a}$ & $16.6 \mathrm{a}$ & $117 \mathrm{a}$ & $14344 \mathrm{a}$ & $123 \mathrm{~b}$ & $16.5 \mathrm{a}$ & $94 \mathrm{a}$ & $11137 \mathrm{a}$ & $119 \mathrm{bc}$ & $16.3 \mathrm{a}$ \\
\hline Severe & $74 \mathrm{a}$ & $9438 \mathrm{a}$ & $127 \mathrm{a}$ & $17.2 \mathrm{a}$ & $86 \mathrm{~b}$ & $10813 \mathrm{~b}$ & $126 a b$ & $17.2 \mathrm{a}$ & $74 \mathrm{a}$ & 9619 a & $130 \mathrm{a}$ & $16.5 \mathrm{a}$ \\
\hline Har Sim & $90 \mathrm{a}$ & $11149 \mathrm{a}$ & $124 \mathrm{a}$ & $16.8 \mathrm{a}$ & $92 \mathrm{~b}$ & $12051 \mathrm{a}$ & $131 \mathrm{a}$ & $15.8 \mathrm{a}$ & $82 \mathrm{a}$ & $10164 \mathrm{a}$ & $124 \mathrm{ab}$ & $16.5 \mathrm{a}$ \\
\hline
\end{tabular}

y Means followed by the same lowercase letter are not statistically different using the $F$ probability values and the PROC MIXED macro as described by Saxton (1998) at $\alpha=0.05$.

${ }^{\mathrm{z}}$ Description of seed cane: Control = no red stripe symptoms evident in seed cane; Mild = mild leaf stripe symptoms only; Severe $=$ extensive leaf stripe, top rot, or both symptoms severe symptoms; and Har Sim = simulated harvester cut seed cane with random red stripe incidence. 
effects of stalk rotting on cane quality (TRS). These effects may become commercially significant as disease incidence increases. Contour plots of soil properties and red stripe ratings further demonstrate the direct and spatial relation between red stripe and sugarcane yields.

Two studies were conducted to investigate the effects of soil type, $\mathrm{N}$ rate, and seed source on red stripe. The effects of these factors on sugarcane yield were also evaluated. The first study clearly demonstrated that higher $\mathrm{N}$ rates increased the extent of the red stripe infection and decreased cane and sugar yields. This effect would be exacerbated on heavy, clay soils, which are becoming more commonly utilized in the Louisiana sugarcane industry due to loss of silt loam soils to urban encroachment. This association between high fertility levels and increased disease incidence was reported in Louisiana for sugarcane brown rust (Johnson et al. 2007). In the second study, the data clearly indicated that utilizing diseased stalks as a seed source could decrease cane and sugar yields, even in subsequent ratoon crops, primarily as the result of poorer stand establishment. These combined data suggest that red stripe may have significant effects on sugarcane yields and that care must be taken to manage the disease through proper use of cultural practices and careful management of infected fields. Specific examples of these practices would include avoiding over-application of $\mathrm{N}$ fertilizer (particularly on heavy soils) and avoiding utilization of heavily infected seed cane. The best strategy to avoid yield loss due to red stripe is through the utilization of resistant varieties.

\section{ACKNOWLEDGMENTS}

This research was supported by funds from the United States Department of Agriculture-Agricultural Research Service. We thank D. Jones, B. King, and J. Rome for assistance in soil sampling and R. Richard for assistance in red stripe monitoring. Mention of a trademark, proprietary product or vendor does not constitute a guarantee or warranty of the product by the United States Department of Agriculture and does not imply its approval to the exclusion of other products or vendors that may also be suitable.

\section{LITERATURE CITED}

Anderson, D. L., Raid, R. N., Irey, M. S., and Henderson, L. J. 1990. Association of sugarcane rust severity with soil factors. Plant Dis. 74:683-686.
Christopher, W. N., and Edgerton, C. W. 1930. Bacterial stripe diseases of sugarcane in Louisiana. J. Agric. Res. 41:259-267.

Edgerton, C. W. 1955. Bacterial diseases. Pages 121-135 in: Sugarcane and Its Diseases. Louisiana State University Press, Baton Rouge.

Egan, B. T., and Hughes, C. G. 1958. Top rot cane cause loses. Cane Grow. Q. Bull. 22:35-36.

Goovaerts, P. 1997. Geostatistics for Natural Resources Evaluation. Oxford University Press, Oxford.

Isaaks, E. H., and Srivastava, R. M. 1989. An Introduction to Applied Geostatistics. Oxford University Press, Oxford.

Johnson, R. M., Grisham, M. P., and Richard, E. P., Jr. 2007. Relationship between sugarcane rust severity and soil properties in Louisiana. Phytopathology 97:748-755.

Johnson, R. M., and Richard, E. P., Jr. 2005. Variability in sugar yield, sugar quality and soil properties in Louisiana sugarcane production systems. Agron. J. 97:760-771.

Legendre, B. L. 1992. The core/press method of predicting the sugar yield from cane for use in payment. Sugar J. 54:2-7.

Martin, J. P., and Wismer, C. A. 1961. Red stripe. Pages 109-126 in: Sugar-Cane Diseases of the World, Vol. 1. J. P. Martin, E. V. Abbott, and C. S. Hughes, eds. Elsevier Science Publishing Company, Amsterdam.

Martin, J. P., and Wismer, C. A. 1989. Red stripe (revised by C. C. Ryan). Pages 81-95 in: Diseases of Sugarcane. Major Diseases. C. Ricaud, B. T. Egan, A. G. Gillaspie, Jr., and C. S. Hughes, eds. Elsevier Science Publishers, B.V., Amsterdam.

Nelson, D. W., and Sommers, L. E. 1996. Total carbon, organic carbon and organic matter. Pages 961-1010 in: Methods of Soil Analysis. Part 3, Chemical Methods. SSSA No. 5. D. L. Sparks, A. L. Page, P. A. Helmke, and R. H. Loeppert, eds. American Society of Agronomy, Madison, WI.

Rott, P., and Davis, M. J. 2000. Red stripe (top rot). Pages 58-62 in: A Guide to Sugarcane Diseases. P. Rott, R. A. Bailey, J. C. Comstock, B. J. Croft, and A. S. Saumtally, eds. CIRAD ISSCT, Montpellier, France.

Sadler, E. J., Busscher, W. J., Bauer, P. J., and Karlen, D. L. 1998. Spatial scale requirements for precision farming: A case study in the Southeastern USA. Agron. J. 90:191-197.

SAS Institute, Inc. 2010. SAS OnlineDoc 9.2. SAS Institute Inc., Cary, NC.

Saxton, A. M. 1998. A macro for converting mean separation output to letter groupings in Proc Mixed. Pages 1243-1246 in: Proc. 23rd SAS Users Group Int. SAS Institute, Cary, NC.

Tew, T. L., Dufrene, E. O., Garrison, D. D., White, W. H., Grisham, M. P., Pan, Y.-B., Richard, E. P., Jr., Legendre, B. L., and Miller, J. D. 2009. Registration of 'HoCP 00-950' Sugarcane. J. Plant Regist. 3:42-50.

Thomas, G. 1996. Soil pH and Soil Acidity. Methods of Soil Analysis. Part 3, Chemical Methods. SSSA No. 5. American Society of Agronomy, Madison, WI. 